\title{
A Breast Tissue Protein Expression Profile Contributing to Early Parity-Induced Protection Against Breast Cancer
}

\author{
Christina Marie Gutierrez ${ }^{a}$ Rebecca Lopez-Valdez ${ }^{a}$ Ramadevi Subramania \\ Arunkumar Arumugam ${ }^{a}$ Sushmita Nandy ${ }^{a}$ Venkatesh Rajamanickam ${ }^{b}$ \\ Vignesh Ravichandran ${ }^{c}$ Rajkumar Lakshmanaswamy ${ }^{a}$
}

aCenter of Excellence in Cancer Research, Department of Biomedical Sciences, Texas Tech University Health Sciences Center, Paul L. Foster School of Medicine, El Paso, 'bivision of Genetic Epidemiology, University of Utah School of Medicine, Salt Lake City, ${ }^{~ C}$ Cancer Biology and Genetics Program, Memorial Sloan-Kettering Cancer Center, New York, USA

\section{Key Words}

Breast cancer $\bullet$ Parity $\bullet$ Prevention $•$ Protein $•$ Biomarkers

\begin{abstract}
Background/Aims: Early parity reduces breast cancer risk, whereas, late parity and nulliparity increase breast cancer risk. Despite substantial efforts to understand the protective effects of early parity, the precise molecular circuitry responsible for these changes is not yet fully defined. Methods: Here, we have conducted the first study assessing protein expression profiles in normal breast tissue of healthy early parous, late parous, and nulliparous women. Breast tissue biopsies were obtained from 132 healthy parous and nulliparous volunteers. These samples were subjected to global protein expression profiling and immunohistochemistry. GeneSpring and MetaCore bioinformatics analysis software were used to identify protein expression profiles associated with early parity (low risk) versus late/nulliparity (high risk). Results: Early parity reduces expression of key proteins involved in mitogenic signaling pathways in breast tissue through down regulation of EGFR1/3, ESR1, AKT1, ATF, Fos, and SRC. Early parity is also characterized by greater genomic stability and reduced tissue inflammation based on differential expression of aurora kinases, p53, RAD52, BRCA1, MAPKAPK-2, ATF-1, ICAM1, and NF-kappaB compared to late and nulli parity. Conclusions: Early parity reduces basal cell proliferation in breast tissue, which translates to enhanced genomic stability, reduced cellular stress/inflammation, and thus reduced breast cancer risk.
\end{abstract}

Rajkumar Lakshmanaswamy

KARGER 125
Center of Excellence in Cancer Research, Department of Biomedical Sciences, MSB1,

Texas Tech University Health Sciences Center, Paul L. Foster School of Medicine, 5001 El Paso Drive, El Paso, Texas 79905, (USA)

Tel. 9152154227, Fax 9157835222, E-Mail rajkumar.lakshmanaswamy@ttuhsc.edu 


\section{Cellular Physiology Cell Physiol Biochem 2015;37:1671-1685 \begin{tabular}{l|l} 
and Biochemistry Published online: November 05, 2015 & $\begin{array}{l}\text { C } 2015 \text { S. Karger AG, Basel } \\
\text { www.karger.com/cpb }\end{array}$ \\
\hline
\end{tabular} \\ Gutierrez et al.: Early Parity-Induced Protein Signature Against Breast Cancer}

\section{Introduction}

Breast cancer is the most predominant cancer in women, currently affecting over 1.6 million women worldwide [1]. Despite improved detection and treatment strategies, breast cancer incidence rates continue to increase [2]. Moreover, metastatic breast cancer quickly acquires resistance to all therapies and there is currently no effective cure [3]. Current therapies for preventing and treating breast cancer also have many undesirable side-effects [3]. Thus, there has been a concerted effort to develop better strategies for prevention and treatment of breast cancer. In this regard, one primary area of study is parity-induced protection against breast cancer [4]. It is well-known that early pregnancy (before age 20) reduces breast cancer risk by as much as 50\% [4-7]. In fact, early and multiple pregnancies further reduce a woman's risk of developing breast cancer by an additional $7 \%$ with each additional pregnancy [8]. In contrast, nulliparity or a first pregnancy later in life (after age 35) increases breast cancer risk [4]. A complete understanding of the natural and universal phenomenon of decreased breast cancer risk in early parous women will allow identification of biomarkers for predicting the risk of both breast cancer development and progression.

This phenomenon of parity-induced protection against breast cancer is also observed in rodent models where we and others have shown that both pregnancy and short-term treatment with pregnancy-level estrogen/progesterone protect against carcinogen-induced mammary cancer [9-14]. Both epidemiologic studies and in vivo rodent studies have revealed notable changes in the systemic hormone and growth factor profiles of parous females [9-11, 15-17]. These persistent systemic alterations have been shown to contribute significantly to parity-induced protection against breast cancer. However, many questions still remain regarding systemic versus local tissue-level changes that mediate the protective effects of early parity. Ongoing investigations suggest that changes in mammary gland responsiveness to hormones and growth-factors may play an important role in parity-mediated protection [18-23]. Indeed, substantial evidence from both epidemiologic and experimental studies indicate that the responsiveness of mammary epithelial cells to hormones and growth factors can change based on differences in receptor subtypes, co-activators, and hormone levels [4]. To date, studies reveal that estrogen receptor alpha (ER-alpha) and epidermal growth factor receptor (EGFR) expression decrease in parous mammary tissue, while ERbeta expression increases [4]. These observations are consistent with decreased estrogen sensitivity and increased cell maturation [4]. Unfortunately, the precise molecular circuitry involved in these changes is still not well-defined.

Recent studies in human subjects have assessed 1) genetic signatures of mammary tissue from parous and nulliparous women [22], [19]; and 2) genetic signatures of mammary tissue from women who have undergone reduction mammoplasty or breast biopsy for benign breast lesions [21]. Our study is therefore an invaluable addition to these prior studies because ours is the first large-scale study to compare the protein expression signatures of normal breast tissue from early parous, late parous, and nulliparous women. In this study, breast tissue biopsies were obtained from completely healthy women not undergoing breastrelated surgery of any kind. With these samples, we have identified a protein expression signature unique to early parous (low risk) versus late/nulliparous (high risk) individuals. This unique protein expression signature significantly expands our understanding of tissuespecific changes that modify breast cancer risk.

\section{Materials and Methods}

Antibodies and reagents

Rabbit polyclonal anti-aurora A, rabbit monoclonal anti-S6K (E175), and rabbit polyclonal IGFR2 were purchased from Abcam Inc (Cambridge, MA, USA). PhosphoExplorer antibody arrays and array assay kits were purchased from Full Moon Biosystems (Sunnyvale, CA, USA). 


\section{Cellular Physiology Cell Physiol Biochem 2015;37:1671-1685

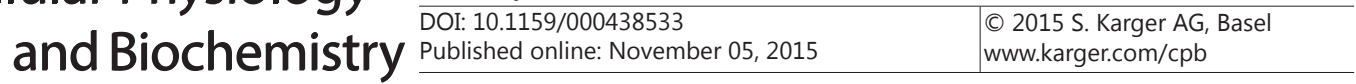 \\ Gutierrez et al.: Early Parity-Induced Protein Signature Against Breast Cancer}

Volunteers, sample collection and processing

Healthy parous and nulliparous women between 40 and 60 yr. of age were recruited for this study at the Dr. Susan Love Research foundation in Santa Monica, CA (Table 1). Volunteer consent protocols for donating breast tissue by core needle biopsy and for the preservation of confidentiality (volunteer identities were not obtained) were reviewed and approved by both the Institutional Review Board of Texas Tech University Health Science Center in El Paso, TX and the Institutional Review Board of the Dr. Susan Love Research Foundation. Ultrasound guided breast tissue biopsies were obtained via core needle biopsy after application of local anesthetic. A small piece was fixed in formalin for histology and remaining tissue was snap frozen for further molecular analysis. Volunteers were divided into three groups: early parous (first fullterm pregnancy $\leq 25 \mathrm{yr}$.), late parous (first full-term pregnancy $\geq 35 \mathrm{yr}$.) and nulliparous (never undergone a full-term pregnancy). All samples were collected at least 5 years after the last full-term pregnancy in all parous women. Only volunteers with a history of regular menses who were not on any medications or oral contraceptives within the last six months prior to sample collection were admitted to the study. Women with liver disease, renal disease, or endocrine problems were not included in the study.

\section{Global protein profiling}

Tissue proteomes of early, late and nulliparous women were probed for the expression of various proteins using the PhosphoExplorer antibody array (Full Moon BioSystems). Briefly lysis beads and extraction buffer were added to $\sim 20 \mathrm{mg}$ of tissue, vortexed for an hour on ice, and centrifuged $(14,000 \mathrm{rpm}$ / $20 \mathrm{~min}$ ). The resulting supernatant was incubated at $-80^{\circ} \mathrm{C}$ for $4 \mathrm{~h}$ followed by a second centrifugation step (14,000 rpm / $20 \mathrm{~min})$. Clarified protein lysates were then applied to the antibody array, followed by fluorescence labeling with Cy3-streptavidin (GE Healthcare, Pittsburgh, PA, USA). Fluorescence intensity was measured using the Axon GenePix Array Scanner (Molecular Devices, Sunnyvale, CA, USA) and normalized to beta-actin expression levels for each array. Changes in protein expression were analyzed using GeneSpring software v. 12.5 (Agilent, Santa Clara, CA, USA).

\section{Immunohistochemistry of human breast tissue}

Individual proteins of interest were probed on formalin fixed, paraffin-embedded normal mammary tissue sections using standard immunohistochemistry techniques. Briefly, sections were deparaffinized and prepared by heat induced antigen retrieval with Trilogy (Cell Marque, Rocklin, CA, USA) at $90^{\circ} \mathrm{C}$ for $1 \mathrm{hr}$. The slides were washed with PBS and incubated 15 min with blocking buffer containing 1\% FBS (Invitrogen, Grand Island, NY, USA) followed by PeroxFree blocking buffer for $5 \mathrm{~min}$. Tissues were then incubated at $4^{\circ} \mathrm{C}$ overnight with IGFR2, P70S6K, or aurora kinase A (Abcam, CA, USA) antibodies as per manufacturer's recommendations. Slides were washed with PBS and overlaid with PolyScan HRP label (Cell Marque, Rocklin, CA, USA) for 30 min, washed again, and then overlaid with DAB chromogen (Cell Marque, Rocklin, CA, USA). Slides were incubated with DAB chromogen until proper color development was observed. Finally,

Table 1. Characteristics of study subjects

\begin{tabular}{lccc}
\hline & & Parity Status & \\
& Early parous & Late parous & Nulliparous \\
\hline Age (mean \pm SD) & $51.5 \pm 6.2 \mathrm{yr}$ & $50.5 \pm 4.4 \mathrm{yr}$ & $51.1 \pm 6.4 \mathrm{yr}$ \\
Elapsed time since last pregnancy & $\geq 5 \mathrm{yr}$ & $\geq 5 \mathrm{yr}$ & $\geq 5 \mathrm{yr}$ \\
Oral contraceptive use over prior $6 \mathrm{~m}$ & none & none & none \\
& & Breast cancer history & \\
Family & none & none & none \\
Personal & none & none & none \\
& & Volunteer sample size & \\
Total volunteers recruited $(\mathrm{n})$ & 44 & 44 & 44 \\
\hline
\end{tabular}


tissue sections were rinsed in DI water, counterstained with hematoxylin, dehydrated with serial of ethanol baths followed by xylene and set with mounting media (Surgipath, Richmond, IL, USA). Representative IHC images were captured with the Nikon Eclipse 50i (Nikon Instruments Inc., USA).

\section{Statistics}

Significant differences in protein expression between samples were assessed using un-paired Student's t-test. Asymptotic p-value computation and multiple correction testing were carried out using the Benjamini-Hochberg procedure. Volcano plots and the Venn diagram were generated using a fold change cutoff of $\geq 1.3$ to identify proteins differentially expressed in early parous versus late and nulliparous groups.

\section{Results}

One hundred thirty two healthy volunteers were recruited for this study (Table 1). Global protein expression patterns of 1,318 phosphorylated and unphosphorylated proteins in breast tissue samples were assessed by protein antibody array. GeneSpring and MetaCore knowledge-based bioinformatics software were used to analyze the resulting data. Briefly,

Fig. 1. Tissue proteome analysis of late and nulliparous women compared to early parous women. GeneSpring bioinformatics analysis software was used to generate (A) protein expression heatmaps from the average expression of proteins in each sample group, (B) Volcano plots with a fold change cutoff of $\geq 1.3$ and a p-value cutoff of $\leq 0.05$ where red squares represent proteins that are differentially expressed in late/nulliparous women compared to early parous women, and (C) a Venn diagram with fold change and p-value cutoffs of $\geq 1.3$ and $\leq 0.05$, respectively. Of particular interest in the Venn diagram are proteins with expression patterns unique to early parous subjects compared to late and nulliparous subjects (see highlighted slices). Early parous (EP, EPT), late parous (LP, LPT), nulliparous (NP, NPT).

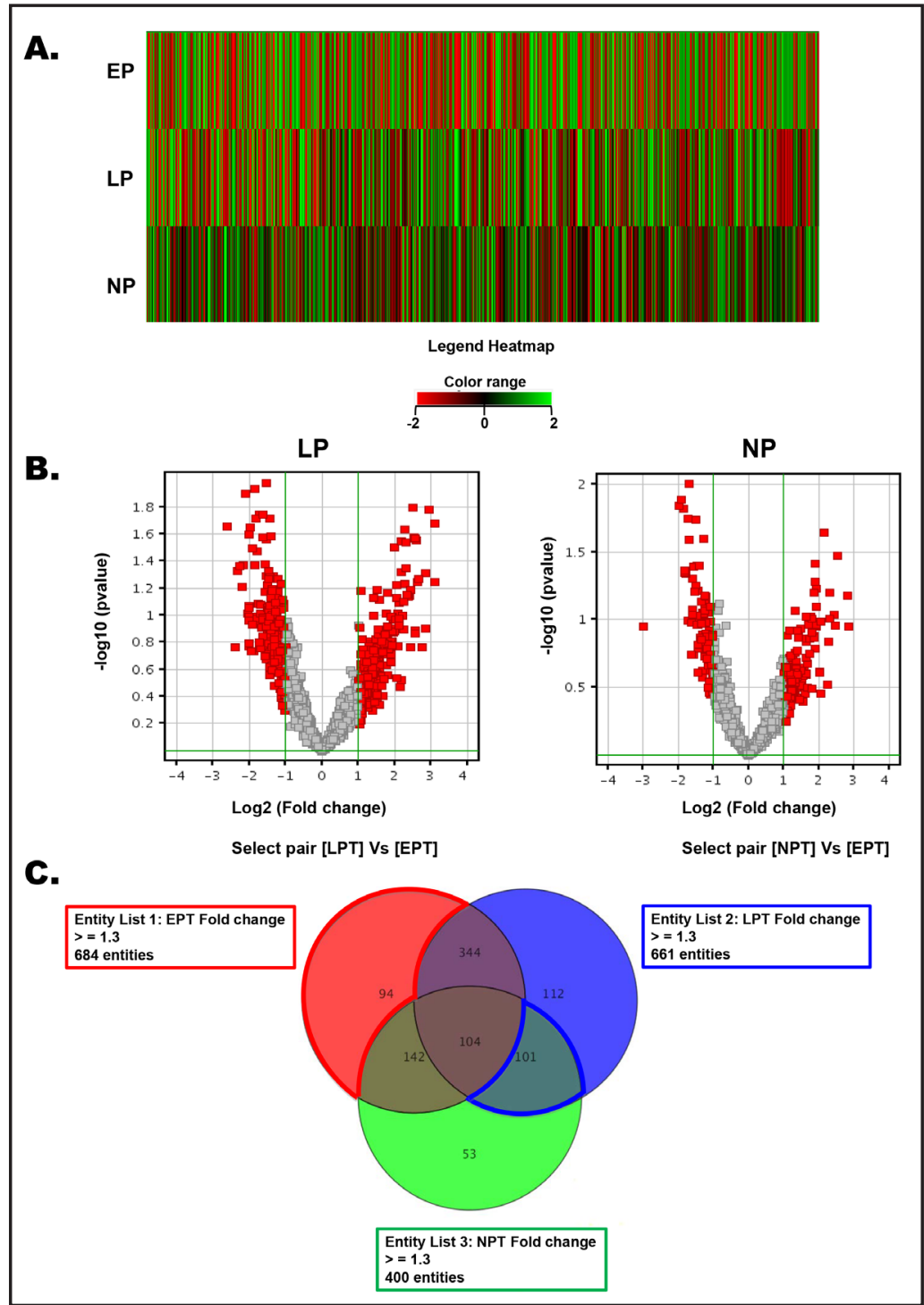




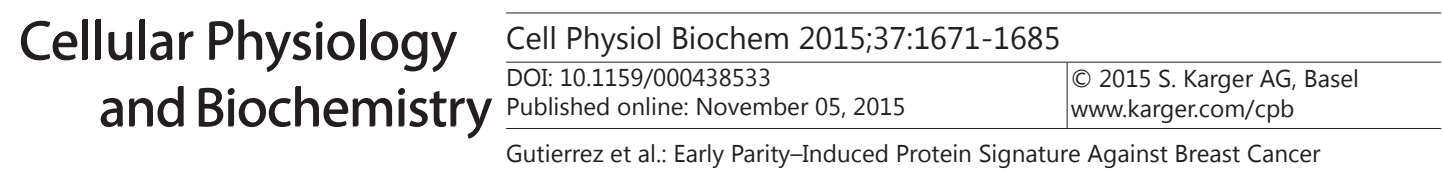

Table 2. Cell Cycle, DNA Damage Response and Apoptosis

\begin{tabular}{|c|c|c|c|c|}
\hline $\begin{array}{l}\text { Protein } \\
\text { Name }\end{array}$ & $\begin{array}{l}\text { Swiss } \\
\text { Prot ID }\end{array}$ & Function & $\begin{array}{l}\text { LP vs. EP } \\
\text { (Fold } \\
\text { Change) }\end{array}$ & $\begin{array}{l}\text { NP vs. EP } \\
\text { (Fold } \\
\text { Change) }\end{array}$ \\
\hline $\begin{array}{l}\text { p53 } \\
\text { (Phospho- } \\
\text { Ser366) }\end{array}$ & & $\begin{array}{l}\text { Serine } 366 \text { phosphorylation by IKK-beta leads to TrCP1- and MDM2- } \\
\text { dependent ubiquitination and degradation of p53. }\end{array}$ & 4.9 & 3.6 \\
\hline $\begin{array}{l}\text { Cyclin B1 } \\
\text { (Phospho- } \\
\text { Ser126) }\end{array}$ & P14635 & $\begin{array}{l}\text { Key role in regulation of cell cycle G2/M transition (mitosis regulation). } \\
\text { Serine } 126 \text { phosphorylation required for CDC2 binding and kinase activity. }\end{array}$ & 3.3 & 1.9 \\
\hline $\begin{array}{l}\text { SMC1 } \\
\text { (Phospho- } \\
\text { Ser957) }\end{array}$ & Q14683 & $\begin{array}{l}\text { Regulates chromosome cohesion during the cell cycle and in DNA repair } \\
\text { processes. Ser957 phosphorylation activates SMC1 and is required for S- } \\
\text { phase checkpoint activity. }\end{array}$ & 3.3 & 2.3 \\
\hline $\begin{array}{l}\text { Survivin } \\
\text { (Phospho- } \\
\text { Thr117) }\end{array}$ & 015392 & $\begin{array}{l}\text { Inhibits apoptosis and also promotes cell proliferation. Facilitates } \\
\text { centromere/midbody docking of AURKB during mitosis with the help of } \\
\text { INCENP. Thr117 phosphorylation by AURKB prevents INCENP-Survivin } \\
\text { interaction. }\end{array}$ & 3.1 & 2.4 \\
\hline $\begin{array}{l}\text { PEA-15 } \\
\text { (Phospho- } \\
\text { Ser116) }\end{array}$ & Q15121 & $\begin{array}{l}\text { Phosphoprotein with key roles in apoptosis inhibition and glucose } \\
\text { transport. Blocks TNF-induced apoptosis by inhibiting caspase } 8 \text {. } \\
\text { Phosphorylation at Ser116 stabilizes protein and inhibits apoptosis. }\end{array}$ & 7.0 & 3.1 \\
\hline $\begin{array}{l}\text { Aurora } \\
\text { Kinase A } \\
\text { (Ab-288) }\end{array}$ & 014965 & Mitosis regulation. Aids in progression of mitosis. & -2.5 & -3.6 \\
\hline $\begin{array}{l}\text { BRCA1 } \\
\text { (Ab-1423) }\end{array}$ & P38398 & Helps maintain genomic stability by facilitating DNA damage responses. & -1.8 & -1.3 \\
\hline $\begin{array}{l}\text { Caspase } 9 \\
(\mathrm{Ab}-196)\end{array}$ & P55211 & $\begin{array}{l}\text { Plays a role in apoptosis activation cascade. Enables apoptosis after DNA- } \\
\text { damage in an ABL1/c-Abl dependent manner. }\end{array}$ & -1.5 & -1.3 \\
\hline $\begin{array}{l}\text { Cyclin E1 } \\
\text { (Ab-77) }\end{array}$ & P24864 & Regulates CDK2 activity in G1/S transition of the cell cycle. & -1.7 & -1.4 \\
\hline $\begin{array}{l}\text { p53 } \\
(\mathrm{Ab}-20)\end{array}$ & P04637 & Cell cycle regulation, DNA damage responses, apoptosis. & -1.4 & -1.3 \\
\hline $\begin{array}{l}\text { p53 } \\
\text { (Phospho- } \\
\text { Thr81) }\end{array}$ & & Threonine 81 phosphorylation stabilizes p53 in stress responses. & -1.7 & -1.3 \\
\hline $\begin{array}{l}\text { MDM2 } \\
(\mathrm{Ab}-166)\end{array}$ & Q00987 & Ubiquitinates p53 targeting it for proteasomal degradation. & -1.9 & -1.4 \\
\hline $\begin{array}{l}\text { RAD52 } \\
\text { (Phospho- } \\
\text { Tyr104) }\end{array}$ & P43351 & $\begin{array}{l}\text { Double-stranded DNA break repair. Homologous recombination. Works } \\
\text { together with RAD51. Tyrosine } 104 \text { phosphorylation activates RAD } 52 \text { DNA } \\
\text { repair functions. }\end{array}$ & -1.5 & -1.5 \\
\hline $\begin{array}{l}\text { PPAR- } \\
\text { gamma } \\
(\mathrm{Ab}-112)\end{array}$ & P37231 & $\begin{array}{l}\text { Glucose homeostasis, cell cycle regulation. Mediates cell survival through } \\
\text { inhibition of BAD and DAPK1. }\end{array}$ & -1.9 & -1.4 \\
\hline
\end{tabular}

raw data from each protein array was first normalized and subjected to a \pm 1.3 fold-change cutoff and a p-value cutoff of $\leq 0.05$. Distinct differences in protein expression were observed for all three groups but there was a subset of proteins in late/nulliparous individuals that shared a common expression pattern distinct from that observed in early parous individuals (Fig. $1 \mathrm{~A}-\mathrm{C}$ ). This particular protein expression profile is likely involved in early paritymediated protection against breast cancer (Fig. 1C).

Early parity alters expression of proteins involved in cell cycle regulation, DNA damage responses and apoptosis

Several proteins involved in the regulation of cell cycle progression and apoptosis were notably altered by early parity (Table 2, Fig. 2A). Late/nulliparous women appear to have lower levels of total aurora kinase A (Table 2). This suggests that protein activation occurs at similar rates between the three groups, but total protein may be less stable or is translated less efficiently in late/nulliparous women. We also observe an increase in inhibitory phosphorylation of survivin, a key component of the chromosomal passenger complex (CPC) in late/nulliparous women (Table 2, Fig. 2A). In addition, the active form of cyclin B1 is highly up regulated in late/nulliparous women compared to early parous women, while cyclin E1 is down regulated in late/nulliparous women (Table 2, Fig. 2A). Active SMC1 (structural maintenance of chromosomes) is up regulated in late/nulliparous women, while BRCA1, p53, and RAD52 levels are down regulated or unstable in late/nulliparous women compared to early parous women (Table 2, Fig. 2A). Total BRCA1 levels are lower in late/ nulliparous women (Table 2) as is the ratio of total-to-phosphorylated protein (Fig. 2A). 


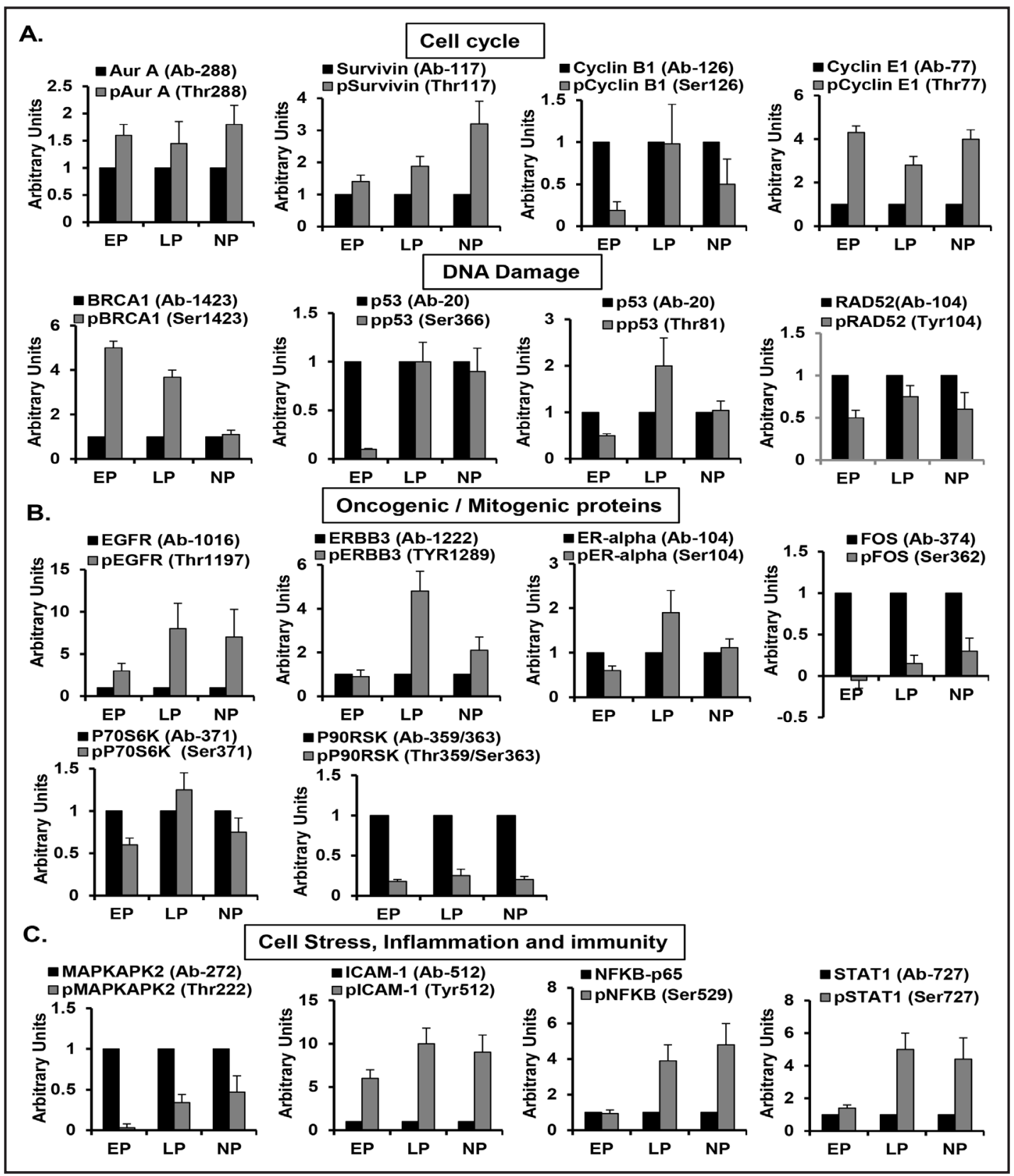

Fig. 2. Ratio of phosphorylated to total protein for key proteins that were differentially expressed in breast tissue according to parity status. Proteins of particular interest to parity-mediated protection against breast cancer were graphed as a ratio of phosphorylated to total protein. This reveals any potential differences in the ratio of total to active or inactive protein in late/nulliparous versus early parous individuals. (A) Proteins that play key roles in cell cycle progression and DNA damage responses, (B) proteins that are known to be proto-oncogenes or have mitogenic effects on breast epithelial cells, (C) proteins with a role in cell stress and inflammation/immune responses. Early parous (EP), late parous (LP), nulliparous (NP).

Similarly, we observe decreased threonine 81 phosphorylation and increased serine-366 phosphorylation of p53 in late/nulliparous women (Table 2, Fig. 2A), which renders p53 susceptible to ubiquitination and degradation $[24,25]$. This indicates potentially impaired p53 activity in late/nulliparous individuals. The active form of RAD52 is also down regulated in late/nulliparous women although there is no difference in the ratio of active to total protein (Table 2, Fig. 2A). This indicates that protein activation likely occurs at similar 
Table 3. Cell Proliferation, Cell Growth

\begin{tabular}{|c|c|c|c|c|}
\hline Protein Name & $\begin{array}{l}\text { Swiss } \\
\text { Prot ID }\end{array}$ & Function & $\begin{array}{l}\text { LP vs. EP } \\
\text { (Fold } \\
\text { Change) }\end{array}$ & $\begin{array}{l}\text { NP vs. EP } \\
\text { (Fold } \\
\text { Change) }\end{array}$ \\
\hline $\begin{array}{l}\text { ABL1 } \\
\text { (Phospho-Tyr204) }\end{array}$ & P00519 & $\begin{array}{l}\text { Cell growth and survival. Cytoskeletal reorganization, cell adhesion and } \\
\text { motility, receptor endocytosis, autophagy, DNA damage response, } \\
\text { apoptosis. Phosphorylation at this site likely activates the protein. }\end{array}$ & 4.5 & 2.5 \\
\hline $\begin{array}{l}\text { AKT1 } \\
\text { (Phospho-Thr450) }\end{array}$ & P31749 & $\begin{array}{l}\text { Signal transduction, cell survival, cell growth, cell adhesion and motility, } \\
\text { cytoskeletal remodeling, immunity, inflammation. Threonine } 450 \\
\text { phosphorylation primes activation. }\end{array}$ & 4.1 & 3.1 \\
\hline $\begin{array}{l}\text { ATF-1 } \\
\text { (Phospho-Ser63) }\end{array}$ & & $\begin{array}{l}\text { Phosphorylation at this site activates the protein in response to } \\
\text { mitogens or cellular stress. }\end{array}$ & 4.7 & 1.5 \\
\hline $\begin{array}{l}\text { EGFR } \\
\text { (Phospho-Tyr1197) }\end{array}$ & P00533 & $\begin{array}{l}\text { Epidermal growth factor receptor. Promotes cell proliferation and } \\
\text { inhibits apoptosis. Autophosphorylated at tyrosine } 1197 \text { upon } \\
\text { activation. }\end{array}$ & 1.7 & 1.3 \\
\hline $\begin{array}{l}\text { ELK-1 } \\
\text { (Phospho-Ser383) }\end{array}$ & P19419 & $\begin{array}{l}\text { Transcription factor. ETS proto-oncogene. Regulates c-Fos expression. } \\
\text { Involved in EGFR signaling, IGF-1 signaling, immunity, inflammation and } \\
\text { development. Phosphorylated at this site by MAPK1 to activate } \\
\text { transcriptional activity. }\end{array}$ & 2.2 & 1.4 \\
\hline $\begin{array}{l}\text { EPO-R } \\
\text { (Phospho-Tyr368) }\end{array}$ & P19235 & $\begin{array}{l}\text { Erythropoietin growth factor signaling. Phosphorylation at this site } \\
\text { associated with apoptosis inhibition. May affect the phenotypes of } \\
\text { certain tumors. }\end{array}$ & 1.5 & 1.6 \\
\hline $\begin{array}{l}\text { Estrogen Receptor- } \\
\text { alpha } \\
\text { (Phospho-Ser104) }\end{array}$ & P03372 & $\begin{array}{l}\text { Nuclear hormone receptor. Female reproductive hormone signaling. } \\
\text { Transcription factor. Important in cell proliferation and differentiation. }\end{array}$ & 1.7 & 1.6 \\
\hline $\begin{array}{l}\text { Ezrin } \\
\text { (Phospho-Tyr353) }\end{array}$ & & $\begin{array}{l}\text { This phosphorylation site activates Ezrin in response to certain growth } \\
\text { signals promoting cell survival, proliferation, and/or migration. }\end{array}$ & 1.5 & 2.0 \\
\hline $\begin{array}{l}\text { SRC } \\
\text { (Phospho-Ser75) }\end{array}$ & & $\begin{array}{l}\text { This modification also leads to ubiquitination/degradation and } \\
\text { cytoskeletal reorganization. }\end{array}$ & 5.4 & 3.1 \\
\hline $\begin{array}{l}\text { GSK3A } \\
\text { (Phospho-Ser9) }\end{array}$ & P49840 & $\begin{array}{l}\text { Energy metabolism regulation, glycogen metabolism. Plays a role in cell } \\
\text { division, proliferation, motility, and survival. Phosphorylates tau and } \\
\text { presenilin-1. }\end{array}$ & 3.2 & 2.7 \\
\hline $\begin{array}{l}\text { PI3-kinase p85- } \\
\text { subunit } \\
\text { alpha/gamma } \\
\text { (Phospho- } \\
\text { Tyr467/Tyr199) }\end{array}$ & P27986 & $\begin{array}{l}\text { Regulatory subunit of the PI3K catalytic subunit. PI3K signaling. } \\
\text { Tyrosine phosphorylation relieves inhibitory activity which allows PI3K } \\
\text { signaling to proceed and enhances cell proliferation, survival, motility, } \\
\text { and morphology. }\end{array}$ & 3.3 & 1.5 \\
\hline $\begin{array}{l}\text { MEK1 } \\
\text { (Phospho-Ser298) }\end{array}$ & Q02750 & $\begin{array}{l}\text { Mitogen-activated protein kinase. Involved in various processes } \\
\text { including proliferation, differentiation and transcriptional regulation. } \\
\text { PAK1 primes MEK1 for activation by RAF-1 through serine } 298 \\
\text { phosphorylation. }\end{array}$ & 5.0 & 1.5 \\
\hline $\begin{array}{l}\text { MER } \\
\text { (Phospho-Tyr749) }\end{array}$ & Q12866 & $\begin{array}{l}\text { Receptor tyrosine kinase. Proto-oncogene. Cell survival, migration, } \\
\text { differentiation, and clearance of apoptotic cells. Autophosphorylation at } \\
\text { Tyr } 749 \text { allows full activation. }\end{array}$ & 2.5 & 5.8 \\
\hline $\begin{array}{l}\text { Fos } \\
\text { (Phospho-Ser362) }\end{array}$ & P01100 & $\begin{array}{l}\text { Signal transduction, cell proliferation and differentiation. } \\
\text { Phosphorylation at this site activates c-Fos and promotes MAPK } \\
\text { signaling. }\end{array}$ & 4.2 & 2.2 \\
\hline $\begin{array}{l}\text { HER3/ErbB3 } \\
(\mathrm{Ab}-1222)\end{array}$ & P21860 & $\begin{array}{l}\text { Neuregulin receptor. Epidermal growth factor signaling. } \\
\text { Heterodimerization with family members possessing kinase activity } \\
\text { results in cell proliferation, differentiation. Overexpressed in various } \\
\text { cancers. }\end{array}$ & 3.3 & 1.4 \\
\hline $\begin{array}{l}\text { FAK } \\
\text { (Phospho-Tyr407) }\end{array}$ & & $\begin{array}{l}\text { Phosphorylation at this site negatively regulates biologic and enzymatic } \\
\text { activity. }\end{array}$ & 2.7 & 2.9 \\
\hline $\begin{array}{l}\text { FYN } \\
\text { (Phospho-Tyr530) }\end{array}$ & P06241 & $\begin{array}{l}\text { SRC family proto-oncogene. PI3-kinase and integrin-mediated signaling. } \\
\text { Cell growth, survival and adhesion. Phosphorylation at this site inhibits } \\
\text { activity. }\end{array}$ & 2.4 & 2.9 \\
\hline $\begin{array}{l}\text { AKT1S1 } \\
{[\mathrm{Ab}-246]}\end{array}$ & Q96B36 & $\begin{array}{l}\text { AKT substrate. Subunit of mTORC1 which negatively regulates mTOR } \\
\text { signaling when unphosphorylated. Phosphorylation by AKT relieves } \\
\text { inhibitory effect on mTOR. }\end{array}$ & -1.9 & -1.4 \\
\hline ATF-1 (Ab-63) & P18846 & $\begin{array}{l}\text { Activating transcription factor. Triggers cell proliferation and } \\
\text { transformation. }\end{array}$ & -2.1 & -1.8 \\
\hline FAK $(A b-910)$ & Q05397 & $\begin{array}{l}\text { Actin cytoskeleton reorganization. Cell migration adhesion and } \\
\text { spreading. Growth factor receptor signaling. }\end{array}$ & -1.6 & -1.4 \\
\hline IGF2R (Ab-2409) & P11717 & $\begin{array}{l}\text { Insulin-like growth factor } 2 \text { receptor. Transports various growth factors } \\
\text { and phosphorylated lysosomal enzymes from the cell surface and Golgi } \\
\text { to lysosomes. Putative tumor suppressor. }\end{array}$ & -1.5 & -2.1 \\
\hline P70S6K (Ab-371) & P23443 & $\begin{array}{l}\text { Translation, cell metabolism, cell growth. Key downstream mediator of } \\
\text { mTOR signaling. }\end{array}$ & -2.7 & -3.2 \\
\hline $\begin{array}{l}\text { P90RSK } \\
(\text { Ab-359/363) }\end{array}$ & Q15418 & $\begin{array}{l}\text { Protein kinase downstream of ERK. Important in mitogen and cell stress } \\
\text { responses. Modulates mTOR signaling and represses apoptosis. }\end{array}$ & -1.4 & -1.3 \\
\hline $\begin{array}{l}\text { SRC } \\
(\mathrm{Ab}-529)\end{array}$ & P12931 & $\begin{array}{l}\text { Non-receptor tyrosine kinase. Proto-oncogene. Phosphorylation at Ser- } \\
75 \text { results in SRC kinase activation during mitosis in fibroblast and } \\
\text { epithelial cells. }\end{array}$ & -2.3 & -1.9 \\
\hline
\end{tabular}

rates in all three groups, but perhaps the stability of the active protein is compromised in late/nulliparous women. Caspase 9-a key component for execution of several apoptotic pathways-is down regulated in late/nulliparous women (Table 2). Finally, elevated levels 
of phoshoPEA-15 could decrease apoptosis by inhibiting caspase 8 and decreased levels of PPAR-gamma expression can mediate cell survival through inhibition of BAD and DAPK1 in late and nulliparous women. All together, these results suggest that compared to early parous women, late/nulliparous women may suffer from a higher level of genomic instability coupled with increased cell proliferation.

Early parity alters expression of proteins involved in cell proliferation/cell growth

Indeed, we have evidence that breast tissue from late/nulliparous women may have a higher rate of cell proliferation compared to breast tissue from early parous women. Many positive regulators of cell proliferation appear to be highly up regulated or activated in late/nulliparous breast tissue including PI3K/AKT, ABL, ATF, EGFR, HER3, ER-alpha, SRC, ELK-1, Ezrin, MEK1, MER, GSK3A and Fos (Table 3, Fig. 2B). However, there are also a few key proteins associated with increased cell proliferation that are down regulated or whose activity is inhibited in late/nulliparous women (Table 3). These include FAK, FYN, P70S6K and P90RSK. Not only are total FAK protein levels lower in late/nulliparous women, we also see up regulation of tyrosine 407 phosphorylation, which inhibits FAK function (Table 3). We further observe an increase in inhibitory phosphorylation of FYN, a SRC family kinase (Table 3). Total P70S6K and P90RSK protein levels are also lower in late/nulliparous women. Meanwhile, there is no difference in the ratio of active-to-total P90RSK in either group (Fig. 2B). Therefore, this protein expression pattern is still consistent with increased cell proliferation in late/nulliparous individuals.

It is also noteworthy that the putative tumor suppressor, IGF2R (insulin-like growth factor 2), is decreased in late/nulliparous breast tissue (Table 3). We know from prior studies that IGF2R expression is associated with decreased IGF2 because IGF2R acts as a molecular sink to control IGF2 levels [26]. Additional studies indicate that IGF2R also regulates other growth factors through its ability to bind mannose-6-phosphate tagged proteins and its function as a shuttle from endosomes to lysosomes [27]. Thus increased IGF2R would be expected to decrease cell proliferation, while decreased levels of IGF2R would be expected to increase cell proliferation in response to various growth factors [26].

Early parity alters expression of proteins involved in cell stress and inflammation

It is perhaps not surprising that late/nulliparous protein profiles also appear to be associated with increased cell stress and inflammation. If cell growth and proliferation are occurring at a higher rate than normal and this is in conjunction with increased genomic instability, then we can also expect higher levels of cellular stress and inflammation. A couple of proteins often activated by cellular stress are up regulated in late/nulliparous individuals compared to early parous individuals (Table 4). These are ATF-1 (pSer63) and MAPKAPK-2 (pThr222). Another series of proteins with proinflammatory functions are also differentially expressed in late/nulliparous women including ICAM-1, NF-kB p65 (pSer529), IkB-beta (p-Thr19), IKK-beta (pTyr188), and STAT1 (pSer727) (Table 4). Several of these proteins also exhibit a clear trend for increased levels of active-to-total protein in late/nulliparous women (Fig. 2C). In a neuroblastoma cell line, both growth factor stimulus and cellular stress activated MAPKAPK-2, which in turn activated CREB and ATF-1 [28]. Also in cortical neurons, activating transcription factor 1 (ATF-1) protects from oxidative stress-induced apoptosis through a hypoxia-inducible pathway involving HIF-1, ATF-1/CREB, p21, and EPO (erythropoietin) [29]. Thus, it is interesting that here we see concurrent up regulation of active MAPKAPK-2, ATF-1 and erythropoietin receptor in late/nulliparous women (Table 3 and 4). It is intriguing to speculate that these proteins may play similar roles in breast epithelial cells where cell stress and/or growth factor stimulus would invoke this particular signaling pathway as a protective mechanism against oxidative and apoptotic stresses.

Further, the fact that ICAM-1 was significantly up regulated in breast tissue of late/ nulliparous women (Table 4, Fig. 2C) is an indication of enhanced inflammation. ICAM-1 is normally expressed at low levels on epithelial cells and other cell types, but is quickly up regulated by inflammatory stimuli [30]. Moreover, ICAM-1 expression is up regulated in

\section{KARGER}




\begin{tabular}{|c|c|c|}
\hline Cellular Physiology & Cell Physiol Biochem 2015;37:1671-1685 & \\
\hline and Biochemistry & $\begin{array}{l}\text { DOI: 10.1159/000438533 } \\
\text { Published online: November 05, } 2015\end{array}$ & $\begin{array}{l}\text { O } 2015 \text { S. Karger AG, Basel } \\
\text { www.karger.com/cpb }\end{array}$ \\
\hline
\end{tabular}

Table 4. Inflammation and Immune Responses

\begin{tabular}{|c|c|c|c|c|}
\hline $\begin{array}{l}\text { Protein } \\
\text { Name }\end{array}$ & $\begin{array}{l}\text { Swiss } \\
\text { Prot ID }\end{array}$ & Function & $\begin{array}{l}\text { LP vs. EP } \\
\text { (Fold } \\
\text { Change) }\end{array}$ & $\begin{array}{l}\text { NP vs. EP } \\
\text { (Fold } \\
\text { Change) }\end{array}$ \\
\hline $\begin{array}{l}\text { ICAM-1 } \\
(\mathrm{Ab}-512)\end{array}$ & P05362 & $\begin{array}{l}\text { CD11a/CD11b integrin receptor. Key role in inflammation. Basal } \\
\text { expression on immune cells, fibroblasts, endothelial cells, and epithelial } \\
\text { cells. Upregulated in response to inflammation. Associated with various } \\
\text { inflammatory immune responses and with epithelial tumorigenesis. }\end{array}$ & 3.7 & 1.3 \\
\hline $\begin{array}{l}\text { IkB-beta } \\
\text { (Phospho- } \\
\text { Thr19) }\end{array}$ & Q15653 & Nuclear factor kappa-B inhibitors. & 4.8 & 6.1 \\
\hline $\begin{array}{l}\text { IKK-beta } \\
\text { (Phospho- } \\
\text { Tyr188) }\end{array}$ & & $\begin{array}{l}\text { Phosphorylation results in degradation and relieves NF-kappa-B } \\
\text { inhibition. }\end{array}$ & 4.0 & 1.7 \\
\hline $\begin{array}{l}\text { MAPKAPK-2 } \\
\text { (Phospho- } \\
\text { Thr222) }\end{array}$ & P49137 & $\begin{array}{l}\text { Stress activated kinase. Cytokine production, cell migration and cell } \\
\text { cycle control. Thr222 phosphorylation by p38 activates the protein. }\end{array}$ & 6.9 & 8.5 \\
\hline $\begin{array}{l}\text { STAT1 } \\
\text { (Phospho- } \\
\text { Ser727) }\end{array}$ & P42224 & $\begin{array}{l}\text { Mediates response to interferons, other cytokines and growth factors. } \\
\text { Important role in regulating cell viability in response to different } \\
\text { stimuli. Ser } 727 \text { phosphorylation mediates IFN-gamma response or } \\
\text { apoptosis induction when DNA damage occurs. }\end{array}$ & 2.3 & 1.3 \\
\hline $\begin{array}{l}\text { NFkB-p65 } \\
\text { (Phospho- } \\
\text { Ser529) }\end{array}$ & Q04206 & $\begin{array}{l}\text { Subunit of the nuclear factor-kappa-B transcription factor complex. } \\
\text { Phosphorylation at this site activates the protein. }\end{array}$ & 5.4 & 2.4 \\
\hline $\begin{array}{l}\text { IKK-GAMMA } \\
(\mathrm{Ab}-31)\end{array}$ & Q9Y6K9 & $\begin{array}{l}\text { Nuclear factor kappa-B activator. Phosphorylates inhibitors of NF-kB. } \\
\text { Mediates certain innate immune functions. }\end{array}$ & -1.8 & -1.4 \\
\hline $\begin{array}{l}\text { NFkB- } \\
\text { p } 100 / \text { p52 } \\
(\text { Ab-865) }\end{array}$ & Q04206 & $\begin{array}{l}\text { Subunit of the nuclear factor-kappa-B transcription factor complex. } \\
\text { Among many functions, involved in regulating inflammation, immunity, } \\
\text { cell growth and apoptosis. }\end{array}$ & -1.6 & -12 \\
\hline $\begin{array}{l}\text { LCK }(\mathrm{Ab}- \\
393)\end{array}$ & P06239 & $\begin{array}{l}\text { Tyrosine kinase. Src family member critical for selection and maturation } \\
\text { of } \mathrm{T} \text { cells. }\end{array}$ & -2.4 & -1.5 \\
\hline $\begin{array}{l}\text { LYN (Ab- } \\
507)\end{array}$ & P07948 & $\begin{array}{l}\text { Non-receptor protein tyrosine kinase. Signaling intermediate. } \\
\text { Regulation of innate and adaptive immunity. Important for proper } \\
\text { immune system activation but also for immune self-tolerance. }\end{array}$ & -1.9 & -1.4 \\
\hline
\end{tabular}

human breast tumor samples compared to adjacent normal tissue and has been linked to enhanced metastatic properties in breast cancer [31]. We also see differential expression of several proteins in the NF-kappa B signaling pathway that indicate enhanced NF-kappa B signaling in late/nulliparous breast tissue (Table 4, Fig. 2D). A primary role for NF-kappa $\mathrm{B}$ in mediating innate immunity and inflammation has been appreciated for decades, and in many cases, has also been linked to cancer development and progression [32]. Further, there are also a few key proteins (IKK-gamma, LCK and LYN) associated with increased innate immunity, $\mathrm{T}$ cell maturation and inflammation that are down regulated in late/nulliparous women (Table 4). All together, these data indicate that compared to early parous breast tissue, late/nulliparous breast tissue may suffer from increased levels of proliferation, genomic instability, stress and inflammation.

These observations are in agreement with MetaCore knowledge-based bioinformatics analysis, which reveals strong associations with signaling pathways favoring cell growth/ proliferation and immunity/inflammation (Fig. 3). Pathway enrichment analysis indicates that estrogen signaling and several other growth factor signaling pathways are enhanced in the late/nulliparous protein expression signature (Fig. 3A). Both gene ontology enrichment and process network analysis also suggest a strong connection with cell cycle regulation and various immune pathways-many of which enhance proinflammatory immunity-in late/ nulliparous individuals (Fig. 3B, 3C). Again, when we subjected late/nulliparous protein expression profiles to MetaCore network analysis, we observed prominent contributions from pathways associated with cellular responses to growth factors (Table 5, Fig. 3D). The top scoring network reveals connections between steroid hormone signaling, epidermal growth factor signaling, and other pro-survival signaling pathways in late/nulliparous protein expression profiles (Fig. 3D).

\section{Immunohistochemistry Protein Array Validation}

In order to further validate the accuracy and reproducibility of these observations, we confirmed expression of key proteins via immunohistochemical (IHC) analysis of breast 


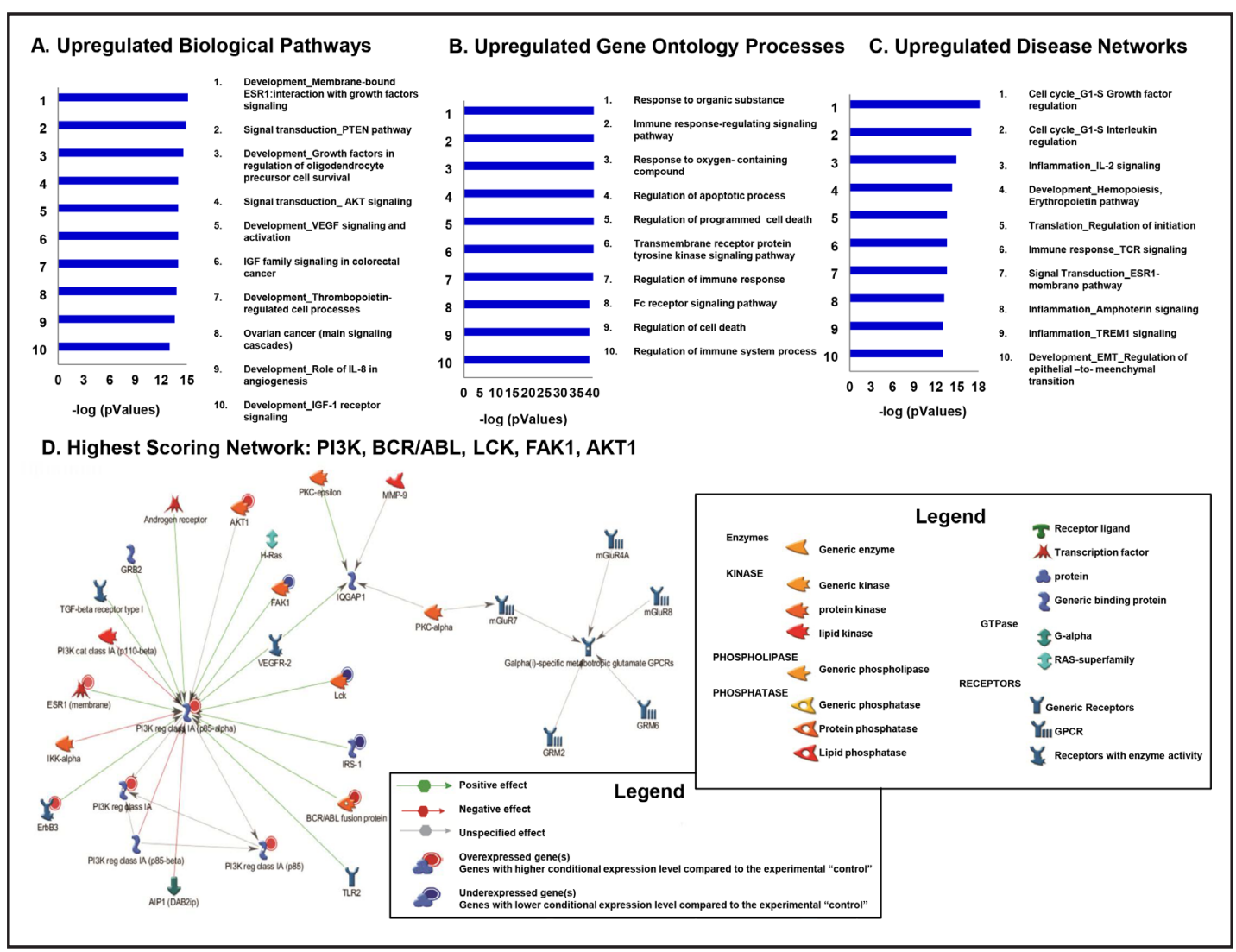

Fig. 3. Enrichment analysis and network analysis of late/nulliparous versus early parous protein expression profiles. (A - C) Gene ontology and functional enrichment analysis was carried out to assess the principal molecular pathways associated with the unique protein expression pattern observed in late/nulliparous versus early parous individuals. Bar length is the negative logarithm of the enrichment p-value determined by MetaCore enrichment analysis. Bar length is therefore a direct measure of how significant the indicated association is. (A) Top ten scoring biological pathways determined by MetaCore enrichment analysis. (B) Top ten scoring gene ontology processes according to MetaCore gene ontology enrichment. (C) Top ten cellular processes associated with the late/nulliparous serum proteome according to MetaCore biomarker enrichment analysis. (D) Top scoring network of the AN algorithm for late/nulliparous versus early parous tissue protein profiles. Directional edges of the network diagram are marked with either green (activation) or red (inhibition) arrows.

epithelial tissue from early, late and nulliparous individuals. For this analysis, IGF2R, P70S6K, and aurora kinase A were chosen based on functional and/or statistical relevance to the study. IHC staining of mammary epithelial cells revealed that each of these proteins follows the same expression pattern as that observed in our protein array results (Fig. 4, Table 2 and 3). In agreement with the protein array results, these proteins are expressed at much higher levels in early parous breast epithelial cells compared to late/nulliparous breast epithelial cells (Fig. 4). Thus, the data from our protein array analysis appears to be accurate and reproducible. Moreover, it is significant that these protein expression patterns were faithfully reproduced specifically in breast epithelial cells (Fig. 4).

\section{Discussion}

The purpose of this study was to identify a protein expression signature unique to early parous women that may be useful in predicting the risk of breast cancer development 


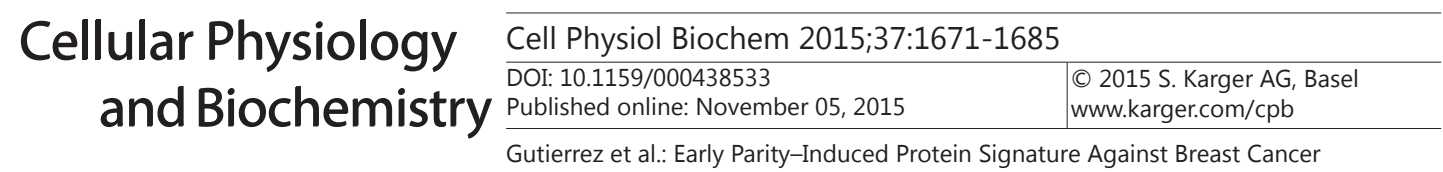

Table 5. Top five networks for the analyze algorithm when comparing late/nulliparous versus early parous tissue protein profiles

\begin{tabular}{|c|c|c|c|c|c|c|c|c|}
\hline No. & Network & GO Processes & $\begin{array}{c}\text { Total } \\
\text { nodes }\end{array}$ & $\begin{array}{c}\text { Seed } \\
\text { nodes }\end{array}$ & $\begin{array}{l}\text { Canonical } \\
\text { pathways }\end{array}$ & $\begin{array}{c}\text { p- } \\
\text { Value }\end{array}$ & zScore & gScore \\
\hline 1 & $\begin{array}{l}\text { PI3K reg class IA } \\
\text { (p85-alpha), } \\
\text { BCR/ABL fusion } \\
\text { protein, Lck, FAK1, } \\
\text { AKT1 }\end{array}$ & $\begin{array}{l}\text { fibroblast growth factor receptor } \\
\text { signaling pathway ( } 46.7 \% ; 1.015 \mathrm{e}- \\
\text { 20), regulation of phosphate } \\
\text { metabolic process ( } 80.0 \% ; 4.372 \mathrm{e}- \\
\text { 20), cellular response to fibroblast } \\
\text { growth factor stimulus ( } 46.7 \% \text {; } \\
\text { 5.374e-20), regulation of phosphorus } \\
\text { metabolic process ( } 80.0 \% \text {; } 5.505 \mathrm{e}- \\
\text { 20), response to fibroblast growth } \\
\text { factor stimulus ( } 46.7 \% ; 6.891 \mathrm{e}-20 \text { ) }\end{array}$ & 30 & 10 & 0 & $\begin{array}{r}3.5 \mathrm{E}- \\
22\end{array}$ & 49.54 & 49.54 \\
\hline 2 & $\begin{array}{l}\text { p70 S6 kinase1, } \\
\text { TAK1(MAP3K7), } \\
\text { AKT(PKB), AKT1, } \\
\text { Elk-1 }\end{array}$ & $\begin{array}{l}\text { cellular response to growth factor } \\
\text { stimulus ( } 65.5 \% \text {; } 6.234 \mathrm{e}-21) \text {, } \\
\text { response to growth factor stimulus } \\
(65.5 \% \text {; } 1.880 \mathrm{e}-20) \text {, positive } \\
\text { regulation of macromolecule } \\
\text { biosynthetic process }(79.3 \% \text {; } 3.147 \mathrm{e}- \\
20) \text {, positive regulation of cellular } \\
\text { biosynthetic process }(79.3 \% ; 2.302 \mathrm{e}- \\
19), \text { positive regulation of gene } \\
\text { expression }(75.9 \% ; 2.692 \mathrm{e}-19)\end{array}$ & 30 & 9 & 0 & $\begin{array}{r}1.4 \mathrm{E}- \\
19\end{array}$ & 44.57 & 44.57 \\
\hline 3 & $\begin{array}{l}\text { FKHR, AKT1, } \\
\text { AKT(PKB), MDM2, } \\
\text { EGFR }\end{array}$ & $\begin{array}{l}\text { fibroblast growth factor receptor } \\
\text { signaling pathway ( } 53.3 \% \text {; } 9.229 \mathrm{e}- \\
25) \text {, cellular response to growth factor } \\
\text { stimulus ( } 70.0 \% \text {; } 5.909 \mathrm{e}-24) \text {, cellular } \\
\text { response to fibroblast growth factor } \\
\text { stimulus (53.3\%; } 6.288 \mathrm{e}-24) \text {, } \\
\text { response to fibroblast growth factor } \\
\text { stimulus (53.3\%; } 8.374 \mathrm{e}-24) \text {, } \\
\text { response to growth factor stimulus } \\
(70.0 \% ; 2.013 \mathrm{e}-23)\end{array}$ & 30 & 9 & 0 & $\begin{array}{r}1.4 \mathrm{E}- \\
19\end{array}$ & 44.57 & 44.57 \\
\hline 4 & $\begin{array}{l}\text { p53, STAT1, MDM2, } \\
\text { IGF-2 receptor, } \\
\text { Cyclin B }\end{array}$ & $\begin{array}{l}\text { regulation of apoptotic process } \\
(65.5 \% \text {; } 3.546 \mathrm{e}-14) \text {, regulation of } \\
\text { programmed cell death }(65.5 \% \text {; } \\
4.167 \mathrm{e}-14) \text {, enzyme linked receptor } \\
\text { protein signaling pathway }(55.2 \% \text {; } \\
4.265 \mathrm{e}-14), \text { regulation of cell death } \\
(65.5 \% ; 9.136 \mathrm{e}-14) \text {, response to lipid } \\
(58.6 \% ; 9.629 \mathrm{e}-14)\end{array}$ & 30 & 7 & 5 & $\begin{array}{r}9.7 \mathrm{E}- \\
15\end{array}$ & 35.22 & 41.47 \\
\hline
\end{tabular}

Fig. 4. Immunohistochemistry of select proteins in early, late, and nulliparous breast epithelial tissue. Changes in protein expression detected by the PhosphoExplorer protein array were confirmed by immunohistochemistry staining of paraffin embedded tissue. Expression patterns of three representative proteins were assessed, including IGF2R (A, B, C), P70S6K (D, E, F), and Aurora Kinase A (G, H, I). Each panel shows the image of an individual mammary duct at $40 \mathrm{X}$ magnification. The first column of images is from early parous tissue samples, the second column from late parous tissue samples, and the last column from nulliparous tissue samples. Images are representative of three replicate experiments.

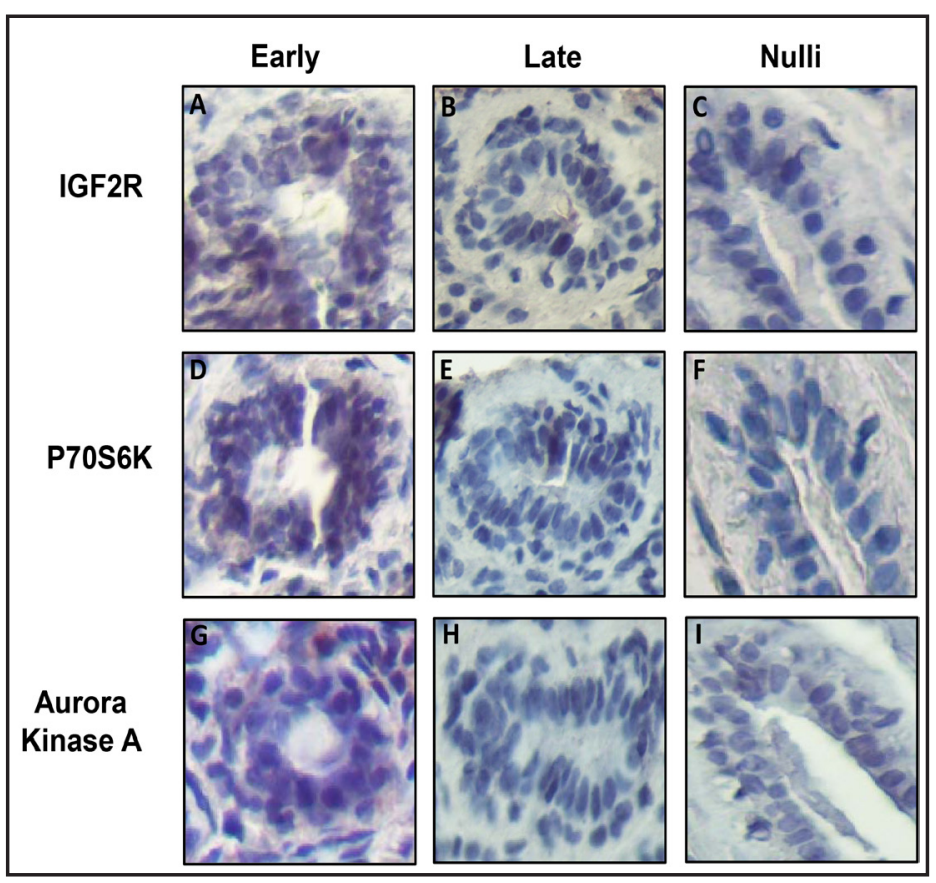


and progression in a diverse population of women. To our knowledge, this is the first largescale study to assess global parity-induced changes at the protein level in normal human breast tissue. It is also our understanding that this is the first study to assess parity-related changes in normal human breast tissue stratified according to early and late parity, as well as, nulliparity. Many prior studies have assessed changes at the transcript level in parous versus nulliparous populations $[4,19,21,22]$. The study design we have implemented here is critical for assessing changes in the mammary gland that truly play a role in parity-related breast cancer protection. There are many parity-related changes in breast tissue that may not play a role in protection against breast cancer or may even play an adverse role in breast cancer risk. In order to distinguish these effects from the true protective effects of parity we have compared protein expression changes in early parous women (low risk group) with protein expression changes commonly shared by both late and nulliparous women (high risk groups). Using this strategy, we successfully identified a protein expression signature unique to early parous women that is distinct from both late and nulliparous women.

This unique protein expression signature indicates that late/nulliparous breast tissue may suffer increased cell proliferation and stress, as well as, increased genomic instability and inflammation. These observations are in line with previous gene expression studies in both humans and rodents where the genomic profile of parous mammary tissue suggests a more mature and less proliferative state compared to non-parous counterparts $[4,19,21,22]$. Indeed, a recent study reported increased levels of Her2 (epidermal growth factor receptor 2) and Esr1 mRNA in nulliparous versus early breast tissue [21]. Although we did not observe increased HER2 protein in this study, we did observe increased levels of two other proteins in the same family-EGFR (HER1) and HER3-in late/nulliparous individuals. Further, we also observed increased levels of ESR1 protein in late/nulliparous vs. early parous women. Thus, it appears that early parity represses human epidermal growth factor and estrogen signaling at both the transcript level [21] and the protein level-two key changes that likely contribute to reduced breast cancer risk in early parous women [4]. In line with increased growth factor and steroid hormone signaling in late/nulliparous women, we also found up regulation of several growth-promoting signaling networks in late/nulliparous breast tissue. These include PI3K/AKT, ATF, FOS and SRC signaling networks.

The concept that a higher degree of cell division can act as a "cancer promoter" for certain types of cancers surfaced in the late 1980's based on epidemiologic evidence [33]. Genotoxic agents such as ionizing radiation or tobacco can by themselves directly cause genetic mutations that may result in malignant transformation. On the other hand, the constant DNA damage rate of a given cell and the resulting amount of irreparable DNA damage can be considered a direct function of that cell's rate of division over time [33]. Thus, any agent or circumstance that enhances cell division would also be expected to promote malignant transformation over an extended period of time. This hypothesis is consistent with breast cancer etiology since hormone dependent breast cancers tend to develop much later in life and account for two thirds of all breast cancer cases [33]. Furthermore, genotoxic insult would be expected to have the most profound effect in a rapidly dividing cell population as opposed to a cell population where proliferation is much lower or even nonexistent, as in the case of Schwann cells which rarely divide and do not form cancers [33]. Therefore, whether increased rates of cell proliferation act alone or in concert with genotoxic insult, we can conclude that higher rates of cell division can significantly increase the risk of breast cancer in late/nulliparous populations.

In agreement with this, we also find evidence of increased genomic instability in late/ nulliparous breast tissue. Aurora kinases A, B, and C are cell cycle proteins essential for appropriate chromosome alignment and segregation during cell division [34]. AurA (aurora kinase $\mathrm{A}$ ) is required for microtubule formation/stabilization at the spindle pole to facilitate appropriate chromosome segregation during mitosis. Insufficient expression of AurA is associated with mitotic abnormalities that culminate in cytokinesis failure and polyploidy [34]. In particular, problems arise when aberrant expression of aurora kinases is accompanied by p53 deficiency as this can lead to aneuploidy or polyploidy [34]. Here, we have evidence that 
p53 activity may be deficient in late/nulliparous women compared to early parous women. Even more concerning is the apparent deficiency in BRCA1 and RAD52 activity. Moreover, threonine-117 phosphorylation of survivin inhibits the association between INCENP and survivin, which can then prevent centromere/midbody docking of AurB during mitosis [34]. Given these observations, it is of particular concern that active cyclin B1 is up regulated in late/nulliparous women because cyclin B1 is essential for pushing the cells through mitosis. Cyclin E1 is expressed at lower levels, suggesting that there may be greater control at the S-phase of the cell cycle in late/nulliparous women. However, faster progression through mitosis is still of great concern as this is the final step in cell division. Therefore, combined p53/BRCA1/RAD52/aurora kinase deficiency and faster progression through mitosis may work together to increase genomic instability in late/nulliparous women. This would increase the chances of malignant transformation. Therefore, an important issue to address in future research is to determine the molecular events responsible for decreased levels/ activity of these critical DNA-damage repair pathways. If these cells are indeed subject to a much greater level of genomic instability, it is likely that this is directly connected to the increased expression of proteins associated with greater cell stress and inflammation in late/nulliparous breast tissue.

In summary, we have shown that early parity is characterized by more efficient expression/activation of breast tumor suppressors p53, RAD52, and BRCA1. In addition, early parity significantly down regulates mitogenic EGFR, ESR1, and other pro-survival signaling pathways. Early parity may also be associated with less cellular stress and dampened inflammatory responses in the breast. This unique protein expression signature further expands our knowledge of how early parity may protect against breast cancer and will be invaluable for identification of breast cancer biomarkers and for development of superior breast cancer prevention/treatment strategies.

\section{Acknowledgements}

We acknowledge Dr. Susan Love for her invaluable help with the recruitment of volunteers for this study. This work was supported by the following Avon Foundation grants: \#02-2011-105.

\section{Disclosure Statement}

The authors declare that there is no conflict of interest.

\section{References}

1 Carter D: New global survey shows an increasing cancer burden. Am J Nurs 2014;114:117.

2 DeSantis C, Ma J, Bryan L, Jemal A: Breast cancer statistics, 2013. CA Cancer J Clin 2014; 64:52-62.

3 de la Mare JA, Contu L, Hunter MC, Moyo B, Sterrenberg JN, Dhanani KC, Mutsvunguma LZ, Edkins AL: Breast cancer: current developments in molecular approaches to diagnosis and treatment. Recent Pat Anticancer Drug Discov 2014;9:153-175.

4 Britt K, Ashworth A, Smalley M: Pregnancy and the risk of breast cancer. Endocr Relat Cancer 2007;14:907933.

5 MacMahon B, Cole P, Lin TM, Lowe CR, Mirra AP, Ravnihar B, Salber EJ, Valaoras VG, Yuasa S: Age at first birth and breast cancer risk. Bull World Health Organ 1970;43:209-221.

6 Henderson BE, Powell D, Rosario I, Keys C, Hanisch R, Young M, Casagrande J, Gerkins V, Pike MC: An epidemiologic study of breast cancer. J Natl Cancer Inst 1974;53:609-614.

7 Kelsey JL: Breast cancer epidemiology: summary and future directions. Epidemiol Rev 1993;15:256-263. 
8 Collaborative Group on Hormonal Factors in Breast Cancer. Breast cancer and breastfeeding: collaborative reanalysis of individual data from 47 epidemiological studies in 30 countries, including 50302 women with breast cancer and 96973 women without the disease. Lancet 2002;360:187-195.

9 Thordarson G, Semaan S, Low C, Ochoa D, Leong H, Rajkumar L, Guzman RC, Nandi S, Talamantes F: Mammary tumorigenesis in growth hormone deficient spontaneous dwarf rats; effects of hormonal treatments. Breast Cancer Res Treat 2004;87:277-290.

10 Rajkumar L, Guzman RC, Yang J, Thordarson G, Talamantes F, Nandi S: Short-term exposure to pregnancy levels of estrogen prevents mammary carcinogenesis. Proc Natl Acad Sci U S A 2001;98:11755-11759.

11 Arumugam A, Subramani R, Nandy S, Lopez R, Boopalan T, Lakshmanaswamy R: Parity and short-term estradiol treatment utilizes similar cellular mechanisms to confer protection against breast cancer. Cell Physiol Biochem 2014;34:491-505.

12 Rajkumar L, Kittrell FS, Guzman RC, Brown PH, Nandi S, Medina D: Hormone-induced protection of mammary tumorigenesis in genetically engineered mouse models. Breast Cancer Res 2007;9:R12.

13 Rajkumar L, Guzman RC, Yang J, Thordarson G, Talamantes F, Nandi S: Prevention of mammary carcinogenesis by short-term estrogen and progestin treatments. Breast Cancer Res 2004;6:R31-37.

14 Guzman RC, Yang J, Rajkumar L, Thordarson G, Chen X, Nandi S: Hormonal prevention of breast cancer: mimicking the protective effect of pregnancy. Proc Natl Acad Sci U S A 1999;96:2520-2525.

15 Bernstein L, Pike MC, Ross RK, Judd HL, Brown JB, Henderson BE: Estrogen and sex hormone-binding globulin levels in nulliparous and parous women. J Natl Cancer Inst 1985;74:741-745.

16 Yu MC, Gerkins VR, Henderson BE, Brown JB, Pike MC: Elevated levels of prolactin in nulliparous women. Br J Cancer 1981;43:826-831.

17 Musey VC, Collins DC, Musey PI, Martino-Saltzman D, Preedy JR: Long-term effect of a first pregnancy on the secretion of prolactin. N Engl J Med 1987;316:229-234.

18 D'Cruz CM, Moody SE, Master SR, Hartman JL, Keiper EA, Imielinski MB, Cox JD, Wang JY, Ha SI, Keister BA, Chodosh LA: Persistent parity-induced changes in growth factors, TGF-beta3, and differentiation in the rodent mammary gland. Mol Endocrinol 2002;16:2034-2051.

19 Verlinden I, Gungor N, Wouters K, Janssens J, Raus J, Michiels L: Parity-induced changes in global gene expression in the human mammary gland. Eur J Cancer Prev 2005;14:129-137.

20 Uehara N, Unami A, Kiyozuka Y, Shikata N, Oishi Y, Tsubura A: Parous mammary glands exhibit distinct alterations in gene expression and proliferation responsiveness to carcinogenic stimuli in Lewis rats. Oncol Rep 2006;15:903-911.

21 Asztalos S, Gann PH, Hayes MK, Nonn L, Beam CA, Dai Y, Wiley EL, Tonetti DA: Gene expression patterns in the human breast after pregnancy. Cancer Prev Res (Phila) 2010;3:301-311.

22 Peri S, de Cicco RL, Santucci-Pereira J, Slifker M, Ross EA, Russo IH, Russo PA, Arslan AA, Belitskaya-Lévy I, Zeleniuch-Jacquotte A, Bordas P, Lenner P, Åhman J, Afanasyeva Y, Johansson R, Sheriff F, Hallmans G, Toniolo P, Russo J: Defining the genomic signature of the parous breast. BMC Med Genomics 2012;5:46.

23 Russo J, Santucci-Pereira J, de Cicco RL, Sheriff F, Russo PA, Peri S, Slifker M, Ross E, Mello ML, Vidal BC, Belitskaya-Lévy I, Arslan A, Zeleniuch-Jacquotte A, Bordas P, Lenner P, Ahman J, Afanasyeva Y, Hallmans G, Toniolo P, Russo IH: Pregnancy-induced chromatin remodeling in the breast of postmenopausal women. Int J Cancer 2012;131:1059-1070.

24 Xia H, Hui KM: MicroRNAs involved in regulating epithelial-mesenchymal transition and cancer stem cells as molecular targets for cancer therapeutics. Cancer Gene Ther 2012;19:723-730.

25 Buschmann T, Potapova O, Bar-Shira A, Ivanov VN, Fuchs SY, Henderson S, Fried VA, Minamoto T, AlarconVargas D, Pincus MR, Gaarde WA, Holbrook NJ, Shiloh Y, Ronai Z: Jun NH2-terminal kinase phosphorylation of p53 on Thr-81 is important for p53 stabilization and transcriptional activities in response to stress. Mol Cell Biol 2001;21:2743-2754.

26 Brown J, Jones EY, Forbes BE: Keeping IGF-II under control: lessons from the IGF-II-IGF2R crystal structure. Trends Biochem Sci 2009;34:612-619.

27 Macdonald RG, Byrd JC: The insulin-like growth factor II/mannose 6-phosphate receptor: implications for IGF action in breast cancer. Breast Dis 2003;17:61-72.

28 Tan Y, Rouse J, Zhang A, Cariati S, Cohen P, Comb MJ: FGF and stress regulate CREB and ATF-1 via a pathway involving p38 MAP kinase and MAPKAP kinase-2. EMBO J 1996;15:4629-4642. 


\section{Cellular Physiology Cell Physiol Biochem 2015;37:1671-1685}

\begin{tabular}{l|l|l|}
\hline DOI: 10.1159/000438533 & O 2015 S. Karger AG, Basel
\end{tabular}

Gutierrez et al.: Early Parity-Induced Protein Signature Against Breast Cancer

29 Zaman K, Ryu H, Hall D, O`Donovan K, Lin KI, Miller MP, Marquis JC, Baraban JM, Semenza GL, Ratan RR: Protection from oxidative stress-induced apoptosis in cortical neuronal cultures by iron chelators is associated with enhanced DNA binding of hypoxia-inducible factor-1 and ATF-1/CREB and increased expression of glycolytic enzymes, p21(waf1/cip1), and erythropoietin. J Neurosci 1999;19:9821-9830.

30 Hubbard AK, Rothlein R: Intercellular adhesion molecule-1 (ICAM-1) expression and cell signaling cascades. Free Radic Biol Med 2000;28:1379-1386.

31 Rosette C, Roth RB, Oeth P, Braun A, Kammerer S, Ekblom J, Denissenko MF: Role of ICAM1 in invasion of human breast cancer cells. Carcinogenesis 2005;26:943-950.

32 Hoesel B, Schmid JA: The complexity of NF-kappaB signaling in inflammation and cancer. Mol Cancer 2013;12:86.

33 Preston-Martin S, Pike MC, Ross RK, Jones PA, Henderson BE: Increased cell division as a cause of human cancer. Cancer Res 1990;50:7415-7421.

34 Hegyi K, Mehes G: Mitotic failures in cancer: Aurora B kinase and its potential role in the development of aneuploidy. Pathol Oncol Res 2012;18:761-769. 